\author{
A. Derevianchenko, O. Fomin, \\ Odessa, Ukraine
}

\title{
ELEMENTS OF APPROACH TO INCREASE RELIABILITY OF CUTTING TOOLS FAILURES RECOGNITION
}

\begin{abstract}
The work is devoted to solving the problem of increasing reliability of cutting tools failures recognition. For this is proposed to carry out the following developments: the formation of sets of direct and indirect features of cutting tools states and failures; forming the corresponding state spaces; reducing their dimensionality by selecting the most informative features; construction of failures classifiers and necessary decision rules. The analysis of methods for selecting failures informative features is carried out, and the genetic method of features selecting is recommended for use.
\end{abstract}

Keywords: failures of cutting tools; recognition; informative features.

\section{INTRODUCTION.}

Modern automated production facilities widely use the corresponding machines - flexible manufacturing modules. These systems work with the limited participation of operators, with their partial intervention (if necessary) in machine control processes. Therefore, all technological operations control and diagnosis processes must be automated.

The largest number of failures of flexible modules is in failures of cutting tools (CT). There are both gradual failures - due to the wear, and sudden failures - due to the destruction of the cutting part (CP). The need to develop appropriate approaches, methods and systems for automatic recognition of tool failures is obviously. Timely failure detection allows to stop the processing and to prevent parts destruction. For this, it is necessary to create appropriate monitoring systems, for which appropriate mathematical and software are developed.

The recognition reliability is determined by such characteristics, as the probability of correct recognition, the values of errors of the first and second kind. They directly depend on the quality of features and classifiers of failures. To increase the reliability of failures recognition, it is necessary to carry out the following developments: the formation of sets of direct and indirect features of CT states and failures; forming the corresponding state spaces; reducing their dimensionality by selecting the most informative features; construction of failures classifiers and necessary decision rules. 
The typical failures of tools for roughing (by the example of cutters) are considered, examples of constructing the corresponding state spaces (with examples of state dynamics - from works states to failure state) are given. The scheme of the system for indirect control (for determining the failure of incisors under shock loads) is given.

The models of uneven wear of CP cutters for finishing, a gradual increase in wear areas, the appearance of concomitant microdefects and the onset of failures, are presented.

Since flexible modules are equipped with tool stores (with a large number of tools for various types of processing), it becomes necessary to construct the corresponding sets of informative features of failures and classifiers. This, in turn, requires the use of methods for selecting informative features. The analysis of these methods is carried out and the genetic method of features selecting is recommended for use.

Research purpose. The purpose of this research is to develop elements of approach to increase the reliability of cutting tools failures recognition.

\section{LITERATURE REVIEW}

Modern metal cutting machines, the corresponding methods and technologies are finding more and more widespread use in modern machinebuilding [1]. With the increasing complexity of modern means of production (and the conditions of their exploitation to the CT quality) the according methods are used in flexible manufacturing modules.

A lot of work has been devoted to improving the quality and optimizing cutting processes, monitoring conditions and evaluating the performance of cutting tools, including works [2 - 8].

According to a number of publications, downtime of modern machine tools in more than half of cases occurs due to gradual or sudden tool failures. The need for the development of modern monitoring methods and systems, mathematical and software for the timely recognition of gradual and sudden CT failures is obvious.

Comparative analysis of conventional and non-conventional optimization techniques for CNC - turning, carried out in [2].

In flexible manufacturing modules high cutting speeds are used [3], which leads to an increase in the wear of the $\mathrm{CT}$ and a reduction in their working life.

A study on automatic on-machine inspection system for 3D modeling and measurement of cutting tools carried out in [4].

Tasks on-line monitoring of tool wear conditions, CT tools failures in machining processes, based on machine tool data, are investigated in [5 - 8]. 
The issues of creating elements of intelligent systems for continuous or periodic CT state diagnosis, obtaining features of states from sensors of direct or indirect control, and the development of the corresponding classifiers are analyzed in [5-8]. It is shown here, that the most important aspect of ensuring high-quality recognition of CT states is - to obtain highly informative features from monitoring systems.

Formation of a system of informative diagnostic features, based on a quantitative expression of their significance, is investigated in [9].

Features of modeling failures of recoverable complex technical objects with a hierarchical constructive structure, formation of a system of informative diagnostic features based on a quantitative expression of their significance, are analyzed in $[10,11]$.

An analysis of the reviewed and many other publications showed the relevance and need for development elements of approach to increase the reliability of cutting tools failures recognition.

\section{RESEARCH METHODOLOGY}

For develop classifiers of sudden failures of cutting tools, it becomes necessary to form models of the dynamics of the $\mathrm{CP}$ states in the corresponding attribute spaces. Adequate decision rules are created. An example of one of these models is shown in Fig. 1.

We introduce a series of notation and write down some relations, which were used by us in [6]:

$X^{F}$ - space of signs of the shape of the contours of wear zones, defects and CP microdefects;

$X_{1}^{F}, X_{2}^{F}, X_{3}^{F}, \ldots, X_{n}^{F}$ - Informative features of the shape of the contours of CP wear zones, defects, microdefects, and CP failures;

$\mathrm{n}$ - number of informative features;

$A_{2}^{T}$ - working area of the flank surface of the worn cutter (the main object of control in conditions of finish turning);

$\Omega_{1}^{F\left[A_{2}^{T}\right]}, \Omega_{2}^{F\left[A_{2}^{T}\right]}, \Omega_{3}^{F\left[A_{2}^{T}\right]}, \ldots, \Omega_{k}^{F\left[A_{2}^{T}\right]}$ - cutting state and CP failures classes;

$k-\mathrm{CP}$ classes quantity;

$x_{F}^{T_{1}}, x_{F}^{T_{2}}, x_{F}^{T_{3}}, \ldots, x_{F}^{T_{p}}$ - feature vector of CP states, obtained at time points of control $T_{1}, T_{1}, T_{1}, \ldots, T_{p}$; 


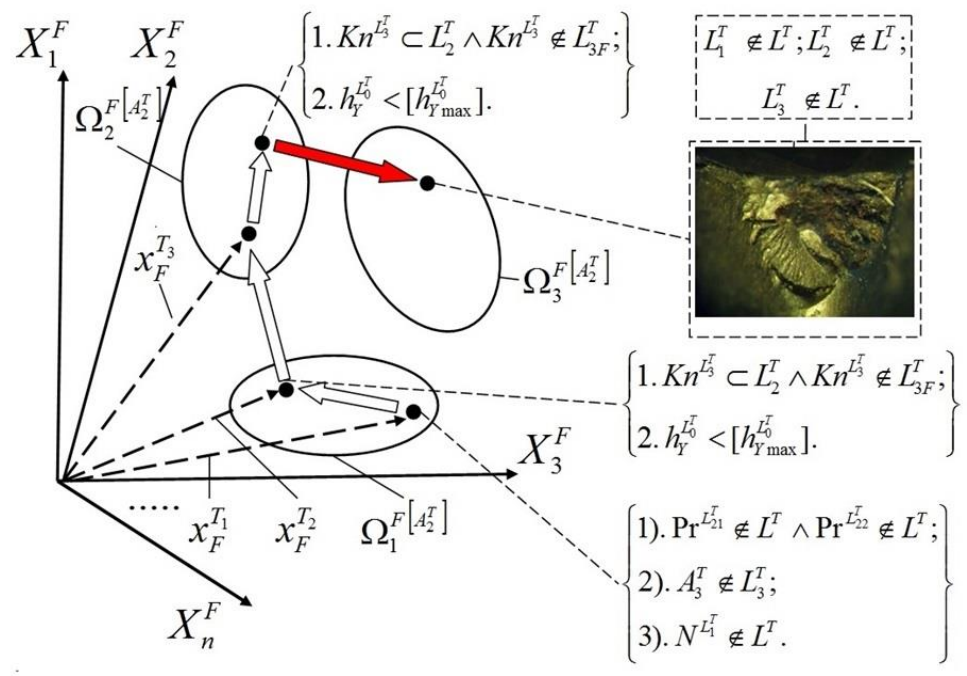

Figure 1 - Representation of the CP cutter states dynamics in the space of geometric features of the surface wear zone (the final CP state is a failure state - chipping)

$K n^{L_{3}^{T}} \notin L_{3}^{T}$ - traces of concentrated wear are present on the flank surface of the CP (but do not affect the quality of the treated surface);

$K n^{L_{3}^{T}} \in L_{3 F}^{T}$ - traces of concentrated wear are present on the flank surface and reach the forming section of the cutting edge - $L_{3 F}^{T}$ (failure state - loss of surface quality);

$h_{Y}^{L_{0}^{T}},\left[h_{Y \max }^{L_{0}^{T}}\right]-$ respectively the current and limit value of the radial wear of the tool;

$\operatorname{Pr}^{L_{21}^{T}}, \operatorname{Pr}^{L_{22}^{T}}$ - grooves respectively on the main and auxiliary flank surfaces of the CP;

$h_{\mathrm{Pr}}^{L_{2}^{T}}, h_{\mathrm{Pr}(\max )}^{L_{2}^{T}}$ - respectively, the current and marginal heights:

$\operatorname{Pr}^{L_{21}^{T}} \notin L^{T}, \operatorname{Pr}^{L_{22}^{T}} \notin L^{T}$ - on the cutting part of the tool ( $L^{T}$ ) there are no grooves.

$N^{L_{1}^{T}}$ - built-up edge on the tools face surface $\left(L_{1}^{T}\right)$. 
CP state are conventionally denoted by black circles - the tops of the state vectors $\left.x_{F}^{T_{1}}, x_{F}^{T_{2}}, x_{F}^{T_{3}}, \ldots, x_{F}^{T_{5}}\right)$, which belong to the classes of $\mathrm{CP}$ states.

Class $\Omega_{3}^{F\left[A_{2}^{T}\right]}$ - a state of CP failure due to a chipping.

Decisive rules for recognition are given on the diagrams in curly brackets.

\section{RESULTS.}

Figures 2, 3 show models of the dynamics of states and various types of failures of the cutters $\mathrm{CP}$.

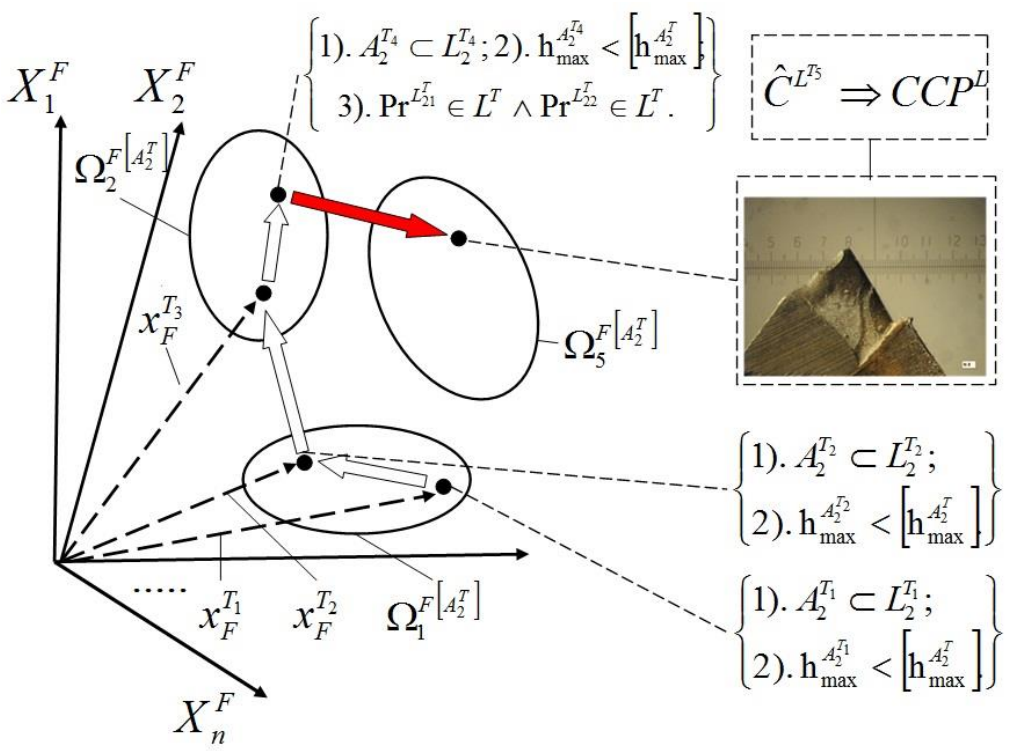

Figure 2 - Representation of the $\mathrm{CP}$ cutter states dynamics in the space of geometric features of the surface wear zone (the final $\mathrm{CP}$ state is a failure state - chipping of the cutting part $\left.\left(\hat{C}^{L^{T_{5}}} \Rightarrow C C P^{L}\right)\right)$

To identify such sudden tool failures, methods and systems for CT monitoring generated, using indirect control methods.

Let us turn to the consideration of the method of indirect control of the states of CT sources. Its main provisions are stated by us in [8], and the scheme for forming patterns of the cutting process (when machining parts with cutter) is shown in Fig. 4. 


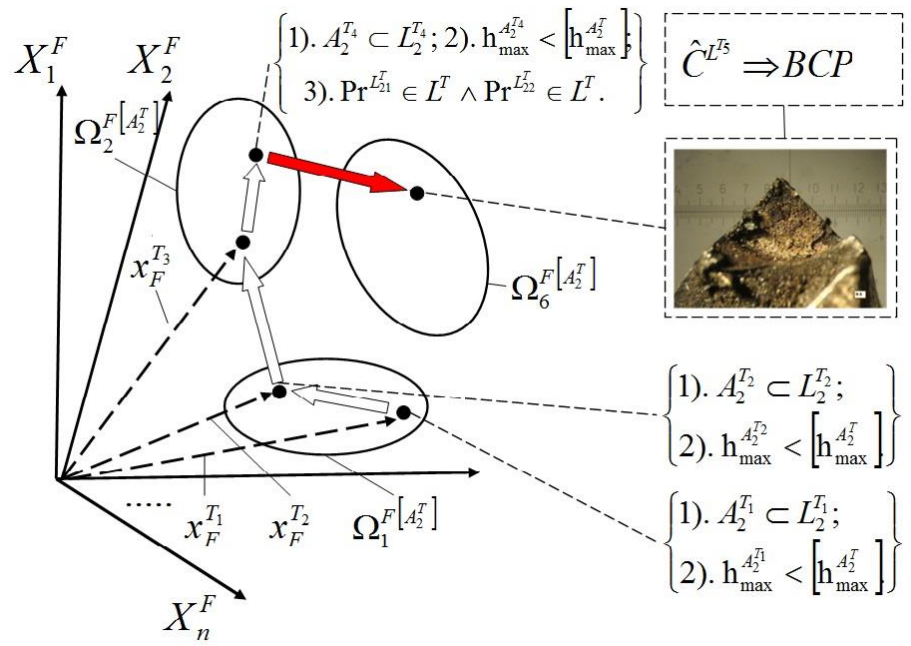

Figure 3 - Representation of the CP cutter states dynamics in the space of geometric features of the surface wear zone (the final CP state is a failure state - breakdown of $\left.\mathrm{CP}\left(\hat{C}^{L^{T_{5}}} \Rightarrow B C P\right)\right)$

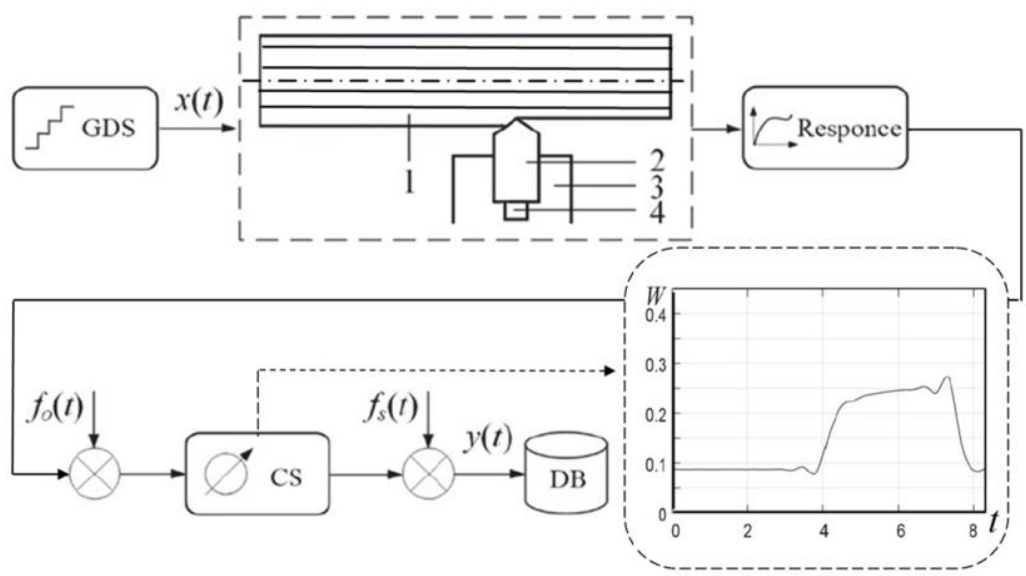

Figure 4 - Schema of the organization of the "input-output" experiment within the framework of the task of diagnosing the cutting process with periodic shock loads [8]: 1 - processed part with longitudinal grooves; 2 - CT (cutter); 3 - cutter holder; 4 indirect control sensor; GDS - pulse loading of the cutting system 
The measuring device - control sensor (SC) and stored in the database (DB). Signals $f_{0}(t)$ and $f_{s}(t)$ are added to the response of the system interference from the cutting process and the sensor, respectively. Indirect control sensor 4, as an element of the automated control system for the electric drive of machine tool, measures the output signal - the active power $W$ of the asynchronous motor. Such a system makes it possible to recognize sudden failures caused by $\mathrm{CP}$ destruction.

Consider the method of $\mathrm{CP}$ failures direct control with the system of technical vision (STV) using. Here, cutting tools states patterns are the digital $\mathrm{CP}$ images. The issues of optimizing the monitoring of incisors using the methods of $\mathrm{CP}$ failures direct control (with the formation of the corresponding features) were considered by us in [7].

Schematic representation of the finishing cutters CP wear features are shown on Fig. 5. During CT operation, especially for fine and precision machining tools, uneven $\mathrm{CP}$ wear, other defects and microdefects occurred.
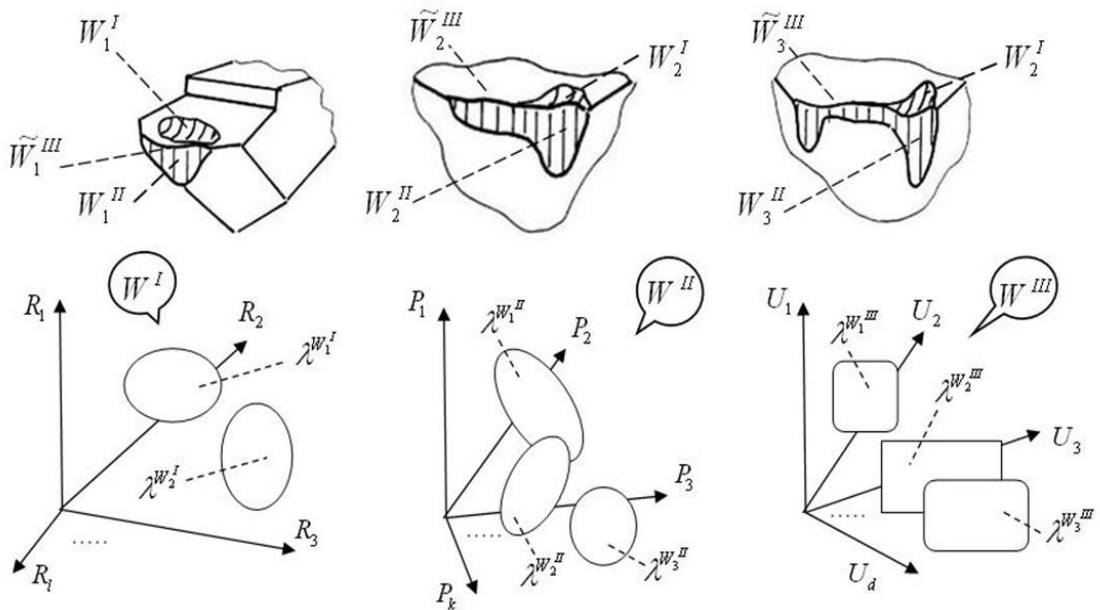

Figure 5-Schematic representation the features of the wear and failures of cutters $\mathrm{CP}$ for finishing treatment

The following notation is used here: types (patterns) of wear zones of the rake face $\left(W_{1}^{I}, W_{2}^{I}\right)$, flank face $\left(W_{1}^{I I}, W_{2}^{I I}, W_{3}^{I I}\right)$ and cutting edges $\left(\tilde{W}_{1}^{I I I}, \tilde{W}_{2}^{I I I}, \tilde{W}_{3}^{I I I}\right)$. 
Accordingly, examples of feature spaces are presented:

- wear zones of the rake face $W^{I}$, with feature sets $\left(R_{1}, R_{2}, \ldots, R_{l}\right)$ and state classes $\left(\lambda^{W_{1}^{I}}, \lambda^{W_{2}^{I}}\right)$;

- wear zones of the flank face $W^{I I}$, with feature sets $\left(P_{1}, P_{2}, \ldots, P_{k}\right)$ and state classes $\left(\lambda^{W_{1}^{I I}}, \lambda^{W_{2}^{I I}}, \lambda^{W_{3}^{I I}}\right)$;

- wear zones of the cutting edges $W^{I I I}$, with feature sets $\left(U_{1}, U_{2}, \ldots, U_{d}\right)$ and state classes $\left(\lambda^{W_{1}^{I I I}}, \lambda^{W_{2}^{I I I}}, \lambda^{W_{3}^{I I I}}\right)$.

An example of representing the space of primary features $W^{I I}$ is shown on Fig. 6.

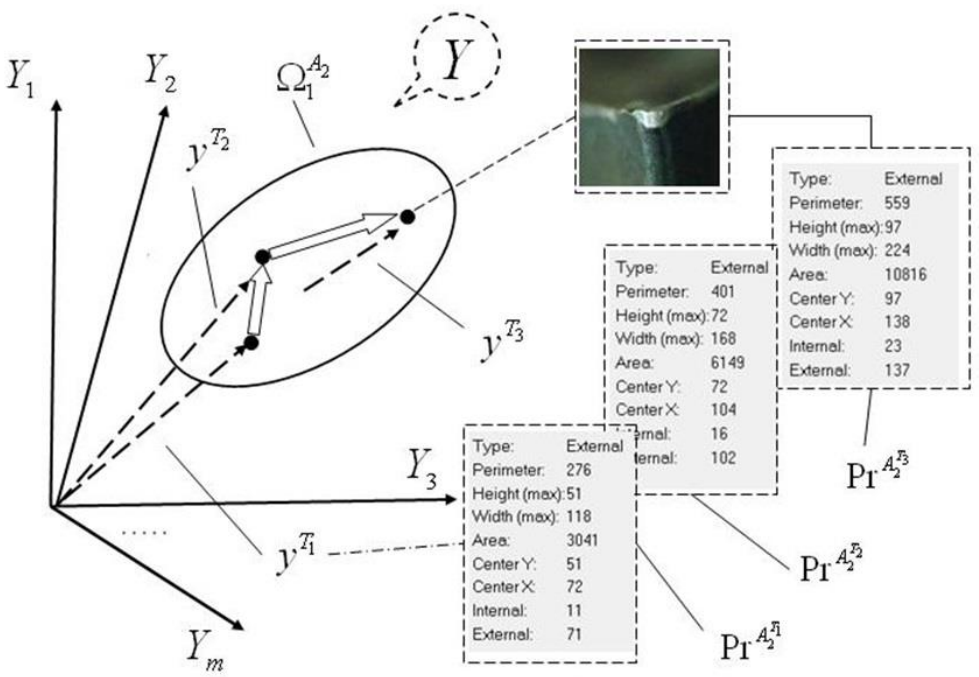

Figure 6 - An example of representing the space of primary features $W^{I I}$ and changes in the condition of the incisors during the period of processing: $T_{1}-T_{3}$

Sets of geometric features of $\mathrm{CP}$ wear zones $\left(\operatorname{Pr}^{A_{2}^{T_{1}}}, \operatorname{Pr}^{A_{2}^{T_{1}}}, \operatorname{Pr}^{A_{2}^{T_{1}}}\right)$ are obtained by processing the corresponding digital images, with using a special software package [6 - 8]. 
The speed of CT monitoring depends on many factors, and first of all from the quantity and quality of decision (diagnostic) rules. A number of methods for reducing the dimension of feature space are known. The task of finding an informative set of features can be solved by exhaustive search, which requires a significant investment of time. Therefore, it is advisable to use other, modern methods.

A schematic representation process of reducing the dimension of the space of CT feature states is shown in Fig. 7.

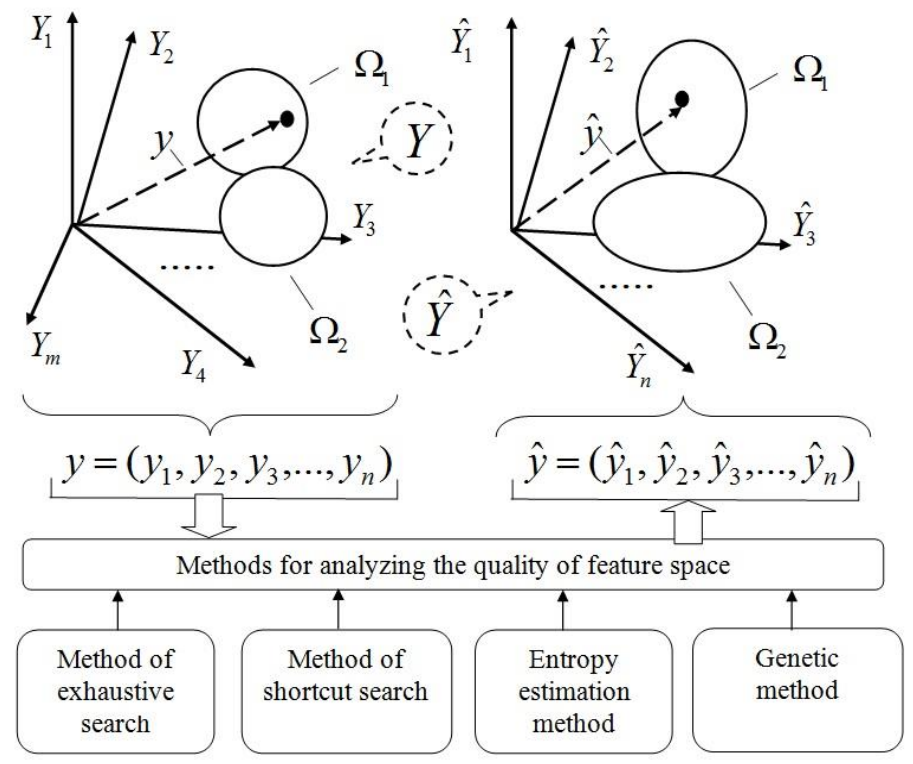

Figure 7 -Schematic representation of the process of reducing the dimension of the space of CT states features

The initial space of primary features $Y$ has dimension $n$. The CT state in this space, which belongs to one of the classes $\left(\Omega_{1}, \Omega_{2}\right)$, is characterized by a vector $y$. The result of its dimension reduction (with one of the methods of quality analysis) is formation of a vector of secondary features $\hat{y}$ by $m$ dimension. Take place relation: $m<<n$.

Fig, 8 shows an example of reducing the dimension of the CP features space by genetic selection of the most informative. Their use provides increased recognition accuracy. 
Notation accepted: $P_{C R i}$ - percentage of correct recognition at each iteration; $m_{1 i}, m_{2 i}$ - corresponding recognition errors of the first and second kind for each iteration; № $\mathrm{i}$ - iteration number; 1_i...12_i - corresponding string labels for each iteration; $\hat{P}_{C R}, \hat{m}_{1}, \hat{m}_{2}$ - respectively, the final results of the recognition quality assessment. Feature codes: 1 - feature is used, 0 feature is not used.

It is quite obvious a significant increase in the basic parameters of recognition reliability.

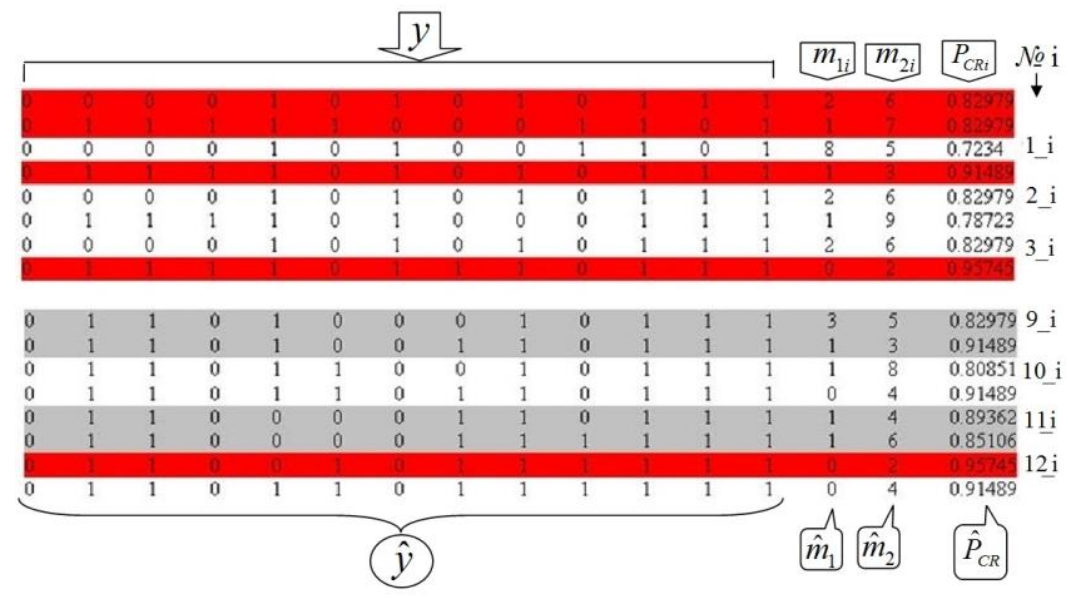

Figure 8 - A table of the results of genetic algorithm using for selecting the most informative characters, that provide increasing of reliability of CT states recognition

\section{CONCLUSION}

1. To increase the reliability of failures recognition, it is necessary to carry out the following developments: the formation of sets of direct and indirect features of CT states and failures; forming the corresponding state spaces; reducing their dimensionality by selecting the most informative features; construction of failures classifiers and necessary decision rules.

2. The typical failures of tools for roughing (by the example of cutters) are considered, examples of constructing the corresponding state spaces (with examples of state dynamics - from works states to failure state) are given. The 
scheme of the system for indirect control (for determining the failure of incisors under shock loads) is given.

3. The models of uneven wear of CP cutters for finishing, a gradual increase in wear areas, the appearance of concomitant microdefects and the onset of failures, are presented.

4. Since flexible modules are equipped with tool stores (with a large number of tools for various types of processing), it becomes necessary to construct the corresponding sets of informative features of failures, and classifiers. This, in turn, requires the use of methods for selecting informative features. The analysis of these methods is carried out and the genetic method of features selecting is recommended for use.

References: 1. Mamalis, A. G. (2006). "Modern aspects of advanced manufacturing", Suchasni tehnologii u mashinobuduvanni, [Modern technologies in mechanical engineering], Vol, 2, Kharkiv, Ukraine, NTU “KhPI”, pp. 58-73. 2. Saravanan, R., Asokan, P. \& Sachithanandam, M. (2001). "Comparative analysis of conventional and non-conventional optimization techniques for CNC turning process", International Journal of Advanced Manufacturing Technology, Vol. 17, Issue 7, pp. 471-476. doi: 10.1007/s001700170146. 3. Liang, S. Y., Hecker, R. L. \& Landers, R.G. (2004). "Machining process monitoring and control: The state-of-the-art", Journal of Manufacturing Science and Engineering, Transactions of the ASME, Vol. 126, Issue 2, pp. 297 310. doi:10.1115/1.1707035. 4. Zhang, X., Tsang, W.-M., Yamazaki, K. \& Mori, M. (2013). “A study on automatic on-machine inspection system for 3D modeling and measurement of cutting tools", Journal of Intelligent Manufacturing, Vol. 24, Issue 1, pp. 71-86. doi: 10.1007/s10845011-0540-6. 5. Lu, Z., Ma, P., Xiao, J., Wang, M. \& Tang,X. (2019). "On-line Monitoring of Tool Wear Conditions in Machining Processes Based on Machine Tool Data" Zhongguo Jixie Gongcheng, China Mechanical Engineering, Vol. 30, Issue 2, pp. 220-225. doi: 10.3969/j.issn.1004-32X.2019.02.013. 6. Derevianchenko A., Fomin A. (2019) Elements of information support of cutting tools dynamics analysis / Cutting and Tools in Technological Systems. Kharkov: NTU «KhPI». V. 91 - pp. 14 - 23. doi: 10.20998/2078-7405.2019.91.02. 7. Derevianchenko O., Fomin O. (2019) Intelligent systems for CNB tools states hardened steel turning. Conference Book of ICACMCT-2019 (International Conference of Advanced Coating and Materials for Cutting Tools), November 21 - 23, Taizhou University, Zhejiang, China. 8. Fomin, O., Pavlenko V., Derevianchenko O., Vodichev V., Ruban O. (2019) An approach to the construction of a nonlinear dynamic model process cutting for diagnosis condition of tools. Applied Aspects of Information Technology, № 2(03), pp. 115-126. doi://10.15276/aait.02.2019.3. 9. Povoroznyuk, A.I. \& Somova, A.A. (2008). Formirovanie sistemy informativnyh diagnosticheskih priznakov na osnovanii kolichestvennogo vyrazhenija ih znachimosti, [Formation of a system of informative diagnostic features based on a quantitative expression of their significance], Herald of the National Technical University "KhPI", Series of "Informatics and Modeling”, No. 24, pp. 137-141. 10. Lenkov, S., Zhyrov, G., Zaitsev, D., Tolok, I., Lenkov, E. (2017). "Features of modeling failures of recoverable complex technical objects with a hierarchical constructive structure", Eastern-European Journal of Enterprise Technologies, Vol 4, No. 4 (88), pp. 34-42. doi: 10.15587/1729-4061.2017.108395. 11. Subbotin, S. \& Oliinyk, A. (2017). "The Sample and Instance Selection for Data Dimensionality Reduction, Recent Advances 
in Systems, Control and Information Technology", Advances in Intelligent Systems and Computing, Vol. 543, pp. 97-103. doi: 10.1007/978-3-319-48923-0_13.

\title{
Олександр Деревянченко, Олександр Фомін, Одеса, Україна
}

\section{ЕЛЕМЕНТИ ПІДХІДУ ДО ПІДВИЩЕННЯ ДОСТОВІРНОСТІ РОЗПІЗНАВАННЯ ВІДМОВ РІЗАЛЬНИХ ІНСТРУМЕНТІВ}

\begin{abstract}
Анотація. Сучасні автоматизовані виробництва широко використовують відповідні верстати - гнучкі виробничі модулі. Ці системи прачюють з обмеженою участю операторів, з їх частковим втручанням (при необхідності) в процеси керування верстатами. Тому усі технологічні операчіï, прочеси контролю та діагностування повинні бути автоматизовані. Найбільша кількість відмов гнучких модулів припадає на відмові різальних інструментів. Мають місие як поступові їх відмови - внаслідок зношування, так і раптові відмови - внаслідок руйнування різальної частини. Очевидна необхідність розробки відповідного підходу, методів та систем автоматичного розпізнавання відмов інструментів. Своєчасне виявлення відмов дозволяе припиняти процес обробки, запобігти пошкодженню деталей. Для иього необхідно створювати відповідні системи моніторингу, для яких розроблясться відповідне математичне та програмне забезпечення. Достовірність розпізнавання визначається такими характеристиками, як вірогідність вірного розпізнавання, значення похибок першого та другого роду. Вони безпосередньо залежать від якості ознак та класифікаторів відмов. Для підвищення достовірності розпізнавання відмов необхідно виконання таких розробок: формування наборів прямих та непрямих ознак станів та відмов РЧ інструментів; побудова відповідних просторів станів; скорочення розмірності просторів станів шляхом відбору найбільш інформативних ознак; побудова класифікаторів відмов інструментів та необхідних вирімальних правил. Розглянуто характерні відмови інструментів для чорнової обробки (на прикладі різців), приведено приклади побудови відповідних просторів станів (з прикладами динаміки станів від станів працездатності до стану відмови). Приведено схему системи непрямого контролю для визначення відмов різиів в умовах ударного навантаження. Приведено моделі нерівномірного зношування РЧ різиів для чистової $i$ фінішної обробки, поступового зростання площин зношування, появи супутніх мікродефектів та виникнення відмов. Оскільки гнучкі модулі оздоблені інструментальними магазинами з великою кількістю інструментів для різних типів обробки, виникає необхідність побудови відповідних множин інформативних ознак станів відмов та класифікаторів. Це, в свою чергу, потребує використання методів відбору інформативних ознак. Проведено аналіз иии методів та запропоновано до використання генетичний метод відбору ознак як найбільш ефективний. Ключові слова. відмови різальних інструментів; розпізнавання; інформативні ознаки.
\end{abstract}

